\title{
Effects of genotypes and explants on garlic callus production and endogenous hormones
}

\author{
Hassan H. A. Mostafa ${ }^{1,2}$, Haiping Wang ${ }^{1}$, Jiangping Song ${ }^{1}$ \& Xixiang $\mathrm{Li}^{1 *}$ \\ High callus production is a feasible way to improve the propagation coefficient of garlic. It remains \\ unknown how genotypes and explants affect garlic callus formation. In the present investigation, we \\ found that there were significant differences in callus formation among garlic varieties. Tip explants \\ were the best calli-producing source, and $91.05 \%$ of the explants from four varieties, on average, \\ formed calli after $45 \mathrm{~d}$ of primary culturing. Upper leaf parts explants produced lower values. Among \\ the different varieties and explant types, tip explants of variety T141 induced calli in the shortest time \\ and had the greatest callus fresh weight at $45 \mathrm{~d}$. An endogenous hormone contents analysis showed \\ that auxins (indole-3-acetic acid and methyl indole-3-acetic acetate), cytokinins (trans-zeatin and \\ dihydrozeatin), gibberellins ${ }_{4,9}, 15,19,24$ and 53 , abscisic acid, jasmonic acid, jasmonoyl-L-isoleucine, and \\ dihydrojasmonic acid were significantly greater in the tips than those in the upper leaf parts. High \\ endogenous jasmonic acid content might play important roles in callus formation. These results will \\ help us not only establish an efficient garlic callus induction protocol that can be applied to large-scale \\ callus multiplication and regeneration, and to genetically improvement of garlic production, but also \\ understand endogenous hormone roles in tissue/organ differentiation and dedifferentiation.
}

Garlic (Allium sativum L.) is an important vegetable crop cultivated worldwide. The commercial varieties of garlic are mainly vegetatively propagated because of its sexual sterility. Consequently, once plants are infected by different viruses, the viruses are transmitted through seed bulbs ${ }^{1}$. In addition, garlic plants in the field have a low propagation rate of approximately 1 to 10 times per year. Therefore, it takes many years to produce a sufficient number of seed bulbs for the practical cultivation of a new variety. Thus, in-vitro tissue culture techniques are feasible alternatives for improving the propagation efficiency, eliminating viruses from infected plants and breeding ${ }^{2}$.

In tissue culture, the callus phase commonly has the objectives of generating genetic variability to obtain new desirable traits and generating transgenic plants to introduce specific traits, such as pest resistance, in Allium crops $^{3-5}$. Furthermore, callus production is also a necessary step for obtaining protoplasts used in protoplast fusion, a useful tool in the multiplication and genetic improvement of vegetatively propagated Allium species for the production of new varieties ${ }^{6,7}$.

In some Allium species, callus induction is difficult, and the proliferation of initial calli is very slow ${ }^{2,8-10}$. Although garlic callus induction has been reported, it is not efficient enough for the rapid mass production of calli $^{11-14}$.

Moreover, in vitro cultures are affected by various factors, such as the media, growth regulators, culture conditions, and the explant tissue source ${ }^{15}$. Various garlic tissues have been used to induce calli, such as root-tips, leaves, immature umbels and basal plates, but there are no reports on using the tips and other leaf parts. Exogenous cytokinins and auxins are important in tissue culture to stimulate various developmental and physiological processes $^{16}$. Cytokinins are categorized as being isoprenoid [N6-2-isopentenyl adenine (IP), trans-zeatin (tZ), cis-zeatin (cZ) and dihydrozeatin (DZ)] or aromatic (N6-benzyladenine, kinetin and topolin) types ${ }^{16}$. Abscisic acid (ABA) and jasmonic acid (JA) are phytohormones involved in the tolerance to abiotic stresses ${ }^{17}$. Growth and differentiation in plant tissue culturing are controlled by interactions among exogenous and endogenous hormones ${ }^{18,19}$. The endogenous hormone levels have important effects on the physiological processes, plant architecture $^{16}$ and the initiation of proliferation centers in explants ${ }^{20}$. They are employed frequently to control cell

${ }^{1}$ Institute of Vegetables and Flowers, Chinese Academy of Agricultural Sciences, The Key Laboratory of Biology and Genetics Improvement of Horticultural Crops, Ministry of Agriculture; 12 Zhongguancun, Nandajie, Haidian District, 100081, Beijing, China. ${ }^{2}$ Central Laboratory of Organic Agriculture, Agricultural Research Centre (Affiliation ID: 60019332), 9 Gamaa Street, 12619, Giza, Egypt. *email: lixixiang@caas.cn 
division ${ }^{17}$. Endogenous hormones are involved in the formation and determination of the morphogenic reactions and their concentrations are spatially and temporally regulated in response to external culture conditions ${ }^{21}$. Previous studies have addressed the associations between changes in hormone types and levels and changes in the medium various callus parameters ${ }^{9,22}$. However, most studies only quantified endogenous hormone levels in produced calli. Reports regarding the endogenous hormone levels in explants were evaluated in other plant species i.e. maize ${ }^{23,24}$, wheat ${ }^{25}$, carrot $^{26}$ and Medicago truncatula Gaertn ${ }^{27}$. However, the effect of the endogenous hormone contents in garlic explants on callus induction and multiplication is poorly understood.

Consequently, this research aimed to develop an efficient callus induction and proliferation technique for large-scale utilization by comparing callus quantities and growth rates of various explants and genotypes and to understand the callus formation-related roles of endogenous hormones in explants.

\section{Results}

Number of days for callus emergence in primary cultures. The number of days required for callus induction in four garlic varieties and their different explants was investigated. There were significant differences $(P<0.01)$ among varieties, explants and their interactions regarding the time needed for calli to emerge (Supplementary Material Figure S1). The earliest sign of callus formation was noticeable on an average of five explants of variety T167 after 18 d (Supplementary Material Figure S1a). VarietiesT141 and T167 required shorter times for callus emergence than T36 and CK $(25 \mathrm{~d})$ from almost all explants. In addition, the mean number of days for callus emergence was greater in the exterior leaves ( $25 \mathrm{~d}$ on average from all varieties) and upper leaf parts ( $24 \mathrm{~d}$ ) (Supplementary Material Figure S1b). The most rapid callus formation was achieved from tip explants $(15 \mathrm{~d})$, followed by lower leaf parts $(21 \mathrm{~d})$. Additionally, the interaction effects of varieties and explants were also evaluated (Supplementary Material Figure S1c). The results showed that the tip explants of variety T141 started to induce callus after 12 days primary culture, with no significant difference from tips of variety T167 (13 days). In contrast, explants from upper part of leave for variety T36 and exterior leaves of variety CK recorded 32 and 31 days for callus occurrence, respectively.

The percentage of explants producing calli for the first time. Different varieties and explants, as well as their interactions, significantly affected the percentage of explants producing calli for the first time (Supplementary Material Figure S2). Varieties CK and T36 showed greater average percentages of explants initiating calli (32.66\% and 32.58\%, respectively) (Supplementary Material Figure S2a). More tip explants, on average, produced calli for the first time $(63.57 \%)$ than other explants, followed by interior leaves $(30.50 \%)$. However, upper leaf parts had the lowest mean percentage of explants producing calli for the first time (15.68\%) (Supplementary Material Figure S2b). According to the interaction effects of varieties and explant types, the tips of varieties CK and T36 had the greatest percentages of explants that initiated calli $(71.87 \%$ and $71.67 \%$, respectively). Meanwhile, the upper leaf-part explants from varieties T141, T167 and T36 produced lower percentages calli for the first time, at 14.04\%, 15.59\% and 15.78\%, respectively (Supplementary Material Figure S2c).

The percentages of total explants producing calli after $45 \mathrm{~d}$ of primary culturing. The statistical analysis revealed that there were significantly differences in the percentages of total explants forming calli among garlic varieties. Varieties CK and T36 were superior to the other varieties, with $49.58 \%$ and $49.40 \%$, respectively, on average, of all explants forming calli (Supplementary Material Figure S3a). Among explant types, 83.26\% of cultured tips produced calli, which was greater than the means of the other five explant types. This was followed by interior leaf explants, with $55.81 \%$ of the explants producing calli. The lowest percentage of total explants initiating calli was observed for upper leaf parts at $23.10 \%$ from all varieties (Supplementary Material Figure S3b). In addition, the different varietal and explant type combinations significantly affected the percentage of the total explants inducing calli $(P<0.01$; Supplementary Material Figure S3c). The maximum percentage was noted from tip explants of variety CK $(91.05 \%)$, but this was not significantly different from the tips of variety T36 (88.00\%). The minimum percentage of the total explants producing calli was obtained from upper leaf parts of varieties T141, CK and T167 (21.89\%, 22.91\% and 23.50\%, respectively).

Callus production after $\mathbf{4 5} \mathbf{d}$ of primary culturing. To determine whether the garlic varieties and explant types affected callus production in primary cultures, the callus weight per flask (g) after $45 \mathrm{~d}$ of culturing was measured (Fig. 1). Variety T141 had a significantly greater average callus weight ( $0.56 \mathrm{~g} /$ flask) for all explants compared with the other four varieties. The lowest callus weight was recorded for variety CK $(0.43 \mathrm{~g} /$ flask) (Fig. 1a). Tips produced the greatest quantity of calli, on average, among all of the garlic varieties $(1.43 \mathrm{~g} /$ flask), followed by interior leaves $(0.42 \mathrm{~g} / \mathrm{flask})$. This difference was the great among callus quantities. The upper leaf parts produced the lowest callus weight per flask over the same period $(0.12 \mathrm{~g}$; Fig. $1 \mathrm{~b})$. The interaction effect between varieties and explants types was highly significant at $P=0.01$ (Fig. 1c). The tip explants of variety T141 had the greatest callus weight per flask, at $2.04 \mathrm{~g}$, after $45 \mathrm{~d}$. However, callus formation decreased to $0.08 \mathrm{~g} / \mathrm{flask}$ from upper leaf parts of the same variety.

Callus cumulative production during subculture. The callus cumulative weight is an important parameter for callus multiplication, somatic embryo induction and plant regeneration. Therefore, the callus weights of four varieties were measured continuously after the $45-\mathrm{d}$ primary induction, during four weeks of subculturing. Supplementary Material Table S1 showed that the effect of explants, genotypes and their interactions on the measured characteristics were highly significant $(P<0.01)$. Variety T36 recorded the greatest callus cumulative weights among all varieties, at $0.89,1.14,1.38$ and $1.67 \mathrm{~g}$ in subculturing $\mathrm{W} 1, \mathrm{~W} 2$, W3 and $\mathrm{W} 4$, respectively. The lowest cumulative weights were obtained from variety CK, at $0.72,0.96,1.17$ and $1.40 \mathrm{~g} /$ flask for subculturing W1, W2, W3 and W4, respectively. Tip explants produced calli with a significantly greater cumulative weight in all varieties $(2.13,2.65,3.13$ and $3.63 \mathrm{~g}$ /flask during subculturing W1, W2, W3 and W4, respectively). This was followed by 

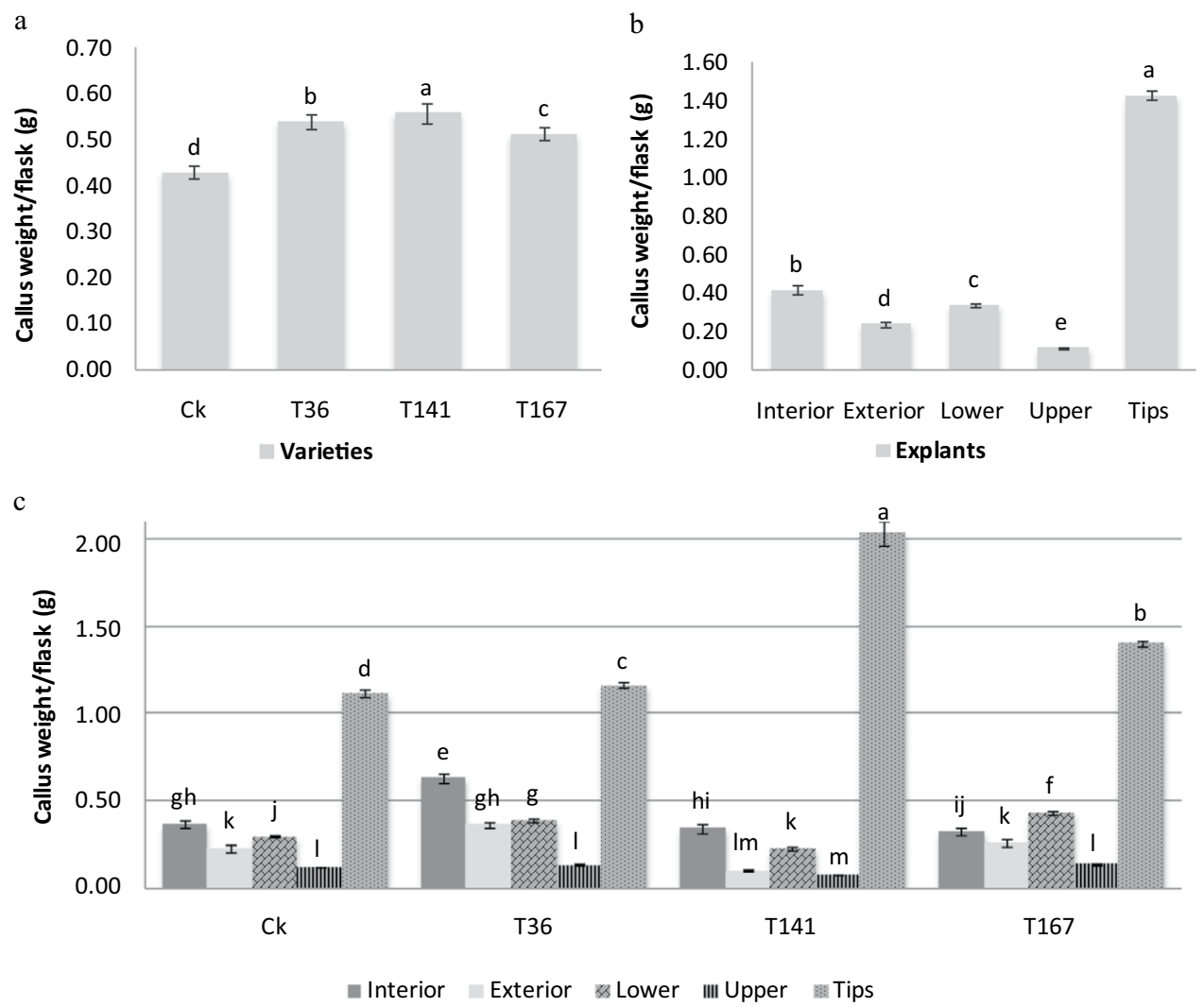

Figure 1. Influence of garlic varieties (a), explants (b) and their interactions (c) on callus weight per flask $(\mathrm{g})$ after $45 \mathrm{~d}$ of primary culturing. Data are presented as means \pm SDs $(\mathrm{n}=3)$ and the different upper letters indicate significant differences at $P<0.05$ level according to LSD test.

interior leaves. In contrast, the lowest callus cumulative weight was of calli produced by upper leaf parts in all varieties, at $0.22,0.30,0.42$ and $0.54 \mathrm{~g}$ /flask during subculturing $\mathrm{W} 1, \mathrm{~W} 2$, W3 and $\mathrm{W} 4$, respectively. Leaf upper parts, in comparison with tip explants, produced 6.74-9.64 times the callus cumulative weight based on all varieties over the 4 weeks. Among the interactions between genotypes and explants, the greatest callus cumulative weight was observed in tip explants of variety T141 during the four weeks of subculturing $(3.03,3.58,4.34$ and $4.99 \mathrm{~g} /$ flask forW1, W2, W3 and W4, respectively). However, over the four consecutive weeks of subculturing, the upper leaf part $(0.15,0.20,0.26$ and $0.31 \mathrm{~g} /$ flask, respectively) or exterior leaf $(0.15,0.20,0.24$ and $0.30 \mathrm{~g} / \mathrm{flask}$, respectively) explants in the same variety (T141) showed the lowest cumulative callus weights.

Callus growth rates (GRs) in subcultures. The callus growth rate (GR) increases at different culture stages might provide a more concise quantitative characteristic of callus development. The GR value gradually decreased in subcultures of all varieties, and the GR of variety T167 was the greatest during W1 (81.33\%), and significantly greater than those of other varieties (Table 1). The GRs for all explant types were greatest during W1 of subculturing and then decreased at different rates. The tip explants had the lowest GR (49.11\%) in W1 among all the explants, and their GR continued to gradually decrease over the four weeks $(49.11 \%, 25.43 \%, 17.69 \%$ and $16.54 \%$, respectively). However, the interior leaf and the upper leaf part had the greatest GR values $(89.08 \%$ and $84.05 \%$, respectively) during W1, but then similarly decreased with time. Interactions between varieties and explants were observed, with the upper leaf part of variety T167 having the greatest GR in W1 (108.57\%), while tips had a GR of only $44.01 \%$. Thus, greater callus production rates were obtained in the primary cultures and at the early stages of the subcultures. It appeared that the greater the production, with a greater callus GR, in the primary culture, the lower the production, with a lower callus GR, in the subculture. Thus, undergoing primary culturing and subculturing for proper time lengths might be very important for total callus production.

Comparison of endogenous hormone contents in different explants. Hormone levels were determined for the explants having the greatest callus production (tips) and lowest callus production (upper leaf parts) of variety T141. The endogenous auxin (IAA, ICA and ME-IAA) contents are presented in Fig. 2a-c. No statistically significant differences were found in the ICA contents between these two explant types. However, the IAA level was greatly higher in tip explants $(3.12 \mathrm{ng} / \mathrm{g})$ and lower in upper leaf parts $(0.35 \mathrm{ng} / \mathrm{g})$. While sharing the same general trend, ME-IAA was much less in the upper leaf parts, at $0.02 \mathrm{ng} / \mathrm{g}$. Additionally, the results of endogenous auxin (IAA and ME-IAA) of varieties Ck, T36 and T167 were in the same trend (Supplementary Material Figure S4). 


\begin{tabular}{|c|c|c|c|c|c|c|c|}
\hline Time & Varieties & Interior $( \pm \mathrm{SD})$ & Exterior $( \pm \mathrm{SD})$ & Lower $( \pm$ SD) & Upper $( \pm$ SD) & Tip $( \pm$ SD $)$ & Mean \\
\hline \multirow{5}{*}{ GR1 } & CK & $100.72 \pm 6.37^{\mathrm{ab}}$ & $83.82 \pm 4.43^{\text {def }}$ & $69.56 \pm 5.32^{\text {hij }}$ & $61.83 \pm 3.40^{0 \mathrm{k}}$ & $54.04 \pm 3.34^{\mathrm{kl}}$ & $73.99^{\mathrm{b}}$ \\
\hline & T36 & $81.11 \pm 3.37^{\mathrm{efg}}$ & $84.23 \pm 12.56^{\mathrm{de}}$ & $67.72 \pm 4.38^{\mathrm{ij}}$ & $75.64 \pm 5.32^{\text {efghi }}$ & $49.63 \pm 1.80^{\operatorname{lm}}$ & $71.67^{\mathrm{b}}$ \\
\hline & T141 & $72.68 \pm 8.55^{\text {ghi }}$ & $46.00 \pm 5.55^{\mathrm{lm}}$ & $93.14 \pm 2.51^{\mathrm{bc}}$ & $90.14 \pm 5.93^{\text {cd }}$ & $48.76 \pm 2.15^{\mathrm{lm}}$ & $70.14^{\mathrm{b}}$ \\
\hline & T167 & $101.79 \pm 4.18^{\mathrm{ab}}$ & $75.02 \pm 1.85^{\text {fghi }}$ & $77.25 \pm 2.52^{\text {efgh }}$ & $108.57 \pm 1.55^{\mathrm{a}}$ & $44.01 \pm 0.96^{\mathrm{m}}$ & $81.33^{\mathrm{a}}$ \\
\hline & Mean & $89.08^{\mathrm{a}}$ & $72.11^{\mathrm{d}}$ & $76.92^{\mathrm{c}}$ & $84.05^{\mathrm{b}}$ & $49.11^{\mathrm{e}}$ & \\
\hline \multirow{5}{*}{ GR2 } & $\mathrm{CK}$ & $34.44 \pm 2.85^{\mathrm{de}}$ & $41.15 \pm 3.89^{\mathrm{bc}}$ & $30.37 \pm 0.88^{\text {defg }}$ & $47.38 \pm 3.58^{\mathrm{a}}$ & $30.41 \pm 2.25^{\text {defg }}$ & $36.75^{\mathrm{a}}$ \\
\hline & T36 & $23.98 \pm 2.96^{\text {gh }}$ & $26.97 \pm 1.37^{\text {fg }}$ & $31.54 \pm 7.85^{\mathrm{def}}$ & $31.79 \pm 3.05^{\text {def }}$ & $27.43 \pm 1.14^{\mathrm{fg}}$ & $28.34^{\mathrm{b}}$ \\
\hline & T141 & $30.49 \pm 5.41^{\text {defg }}$ & $28.49 \pm 3.13^{\text {efg }}$ & $42.05 \pm 2.98^{\mathrm{ab}}$ & $31.46 \pm 4.64^{\text {def }}$ & $18.24 \pm 1.40^{\mathrm{h}}$ & $30.14^{\mathrm{b}}$ \\
\hline & T167 & $24.79 \pm 5.45^{\mathrm{gh}}$ & $29.27 \pm 0.95^{\text {efg }^{2}}$ & $35.38 \pm 4.45^{\mathrm{cd}}$ & $31.58 \pm 8.72^{\text {def }}$ & $25.64 \pm 1.26^{\mathrm{fg}}$ & $29.33^{\mathrm{b}}$ \\
\hline & Mean & $28.42^{\mathrm{c}}$ & $31.47^{\mathrm{b}}$ & $34.84^{\mathrm{a}}$ & $35.55^{\mathrm{a}}$ & $25.43^{\mathrm{d}}$ & \\
\hline \multirow{5}{*}{ GR3 } & $\mathrm{CK}$ & $25.42 \pm 0.88^{\mathrm{de}}$ & $21.86 \pm 4.32^{\mathrm{ef}}$ & $14.72 \pm 4.00^{\mathrm{gh}}$ & $36.51 \pm 3.24^{\mathrm{b}}$ & $20.63 \pm 1.09^{\text {ef }}$ & $23.83^{\mathrm{b}}$ \\
\hline & T36 & $21.91 \pm 2.85^{\mathrm{ef}^{\mathrm{f}}}$ & $30.01 \pm 3.93^{\mathrm{bc}}$ & $28.40 \pm 3.94^{\mathrm{cd}}$ & $49.33 \pm 6.18^{\mathrm{a}}$ & $9.64 \pm 2.29^{\mathrm{h}}$ & $27.86^{\mathrm{a}}$ \\
\hline & T141 & $20.01 \pm 4.30^{\mathrm{efg}}$ & $20.15 \pm 1.8^{\text {efg }}$ & $32.10 \pm 0.64^{\mathrm{bc}}$ & $31.79 \pm 3.89^{\mathrm{bc}}$ & $21.23 \pm 0.64^{\mathrm{ef}}$ & $25.06^{\mathrm{ab}}$ \\
\hline & T167 & $20.25 \pm 4.19^{\text {efg }}$ & $18.67 \pm 3.13^{\mathrm{fg}}$ & $22.61 \pm 1.22^{\mathrm{ef}}$ & $36.76 \pm 3.75^{\mathrm{b}}$ & $19.27 \pm 1.16^{\mathrm{fg}}$ & $23.51^{\mathrm{b}}$ \\
\hline & Mean & $21.90^{\mathrm{b}}$ & $22.67^{\mathrm{b}}$ & $24.46^{\mathrm{b}}$ & $38.60^{\mathrm{a}}$ & $17.69^{\mathrm{c}}$ & \\
\hline \multirow{5}{*}{ GR4 } & $\mathrm{CK}$ & $22.13 \pm 1.22^{\mathrm{de}}$ & $16.95 \pm 4.19^{\mathrm{gh}}$ & $9.51 \pm 1.96^{j}$ & $21.90 \pm 4.92^{\text {defg }}$ & $21.73 \pm 0.91^{\text {defg }}$ & $18.45^{\mathrm{c}}$ \\
\hline & T36 & $22.06 \pm 1.45^{\text {def }}$ & $28.39 \pm 3.01^{\mathrm{bc}}$ & $13.34 \pm 5.18^{\text {hij }}$ & $37.59 \pm 6.08^{\mathrm{a}}$ & $17.62 \pm 1.21^{\text {efgh }}$ & $20.72^{\mathrm{a}}$ \\
\hline & T141 & $14.74 \pm 1.31^{\mathrm{hi}}$ & $25.68 \pm 3.10^{\mathrm{cd}}$ & $15.66 \pm 0.37^{\mathrm{hi}}$ & $20.80 \pm 0.12^{\text {defg }}$ & $14.93 \pm 0.35^{\mathrm{hi}}$ & $18.36^{c}$ \\
\hline & T167 & $17.50 \pm 2.36^{\text {efgh }}$ & $17.25 \pm 2.71^{\mathrm{fgh}}$ & $23.78 \pm 2.83^{\mathrm{cd}}$ & $33.18 \pm 2.90^{\mathrm{ab}}$ & $11.88 \pm 0.44^{\mathrm{ij}}$ & $20.72^{\mathrm{b}}$ \\
\hline & Mean & $19.11^{\mathrm{c}}$ & $22.06^{\mathrm{b}}$ & $15.57^{\mathrm{d}}$ & $28.38^{\mathrm{a}}$ & $16.54^{\mathrm{d}}$ & \\
\hline
\end{tabular}

Table 1. The callus growth rate (GR, \%) of subculture over primary culture as influenced by garlic varieties and various explants. Values are given as the mean \pm standard deviation $(n=3)$. Different letters indicate statistically differences among varieties, explants and their interaction.
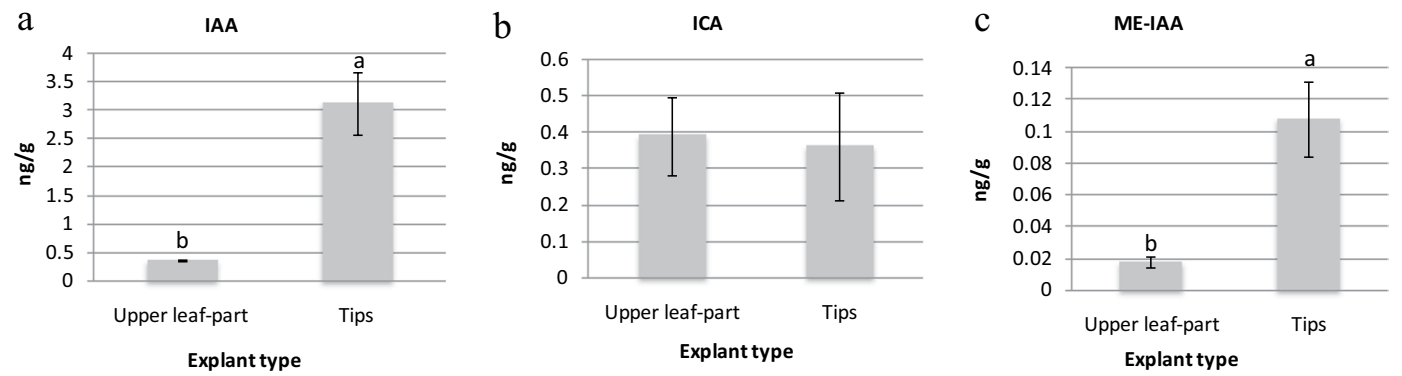

Figure 2. Auxin contents in upper leaf part and tip explants of variety T141: (a) indole-3-acetic acid (IAA), (b) indole-3-carboxaldehyde (ICA) and (c) methyl indole-3-acetate (ME-IAA). Data are presented as means \pm SDs $(\mathrm{n}=3)$ and the different upper letters indicate significant differences at $P<0.05$ level according to LSD test.

Cytokine (IP, cZ, and tZ) concentrations in the two explant types of variety T141 were highly significantly different (Fig. 3). Significantly greater levels of the $t Z$ were found in tip explants, at $0.16 \mathrm{ng} / \mathrm{g}$, than that in upper leaf-part explants. However, upper leaf-part explants had the significantly greater values for IP and cZ hormones at $0.07 \mathrm{ng} / \mathrm{g}$ and $0.22 \mathrm{ng} / \mathrm{g}$, respectively.

As shown in Fig. 4a,b, there was variation in the GA contents between the different explant types. GA 4 and $\mathrm{GA}_{9}$ were found in tip explants $(0.68 \mathrm{ng} / \mathrm{g}$ and $0.20 \mathrm{ng} / \mathrm{g}$, respectively) but were not presented in the upper leaf part explants. Same trend was found for other three varieties for $\mathrm{GA}_{9}$ (Supplementary Material Figure S5a). In contrast, $\mathrm{GA}_{20}$ was found only in upper leaf-part explants, at $2.95 \mathrm{ng} / \mathrm{g}$. In addition, significantly greater concen-

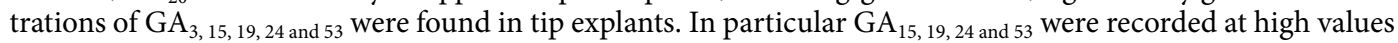
of $43.56,48.8,26.63$ and $30.19 \mathrm{ng} / \mathrm{g}$, respectively. In the same trend, $\mathrm{GA}_{15}$ and $\mathrm{GA}_{24}$ were greatly higher in tip explants of varieties CK, T36 and T167 (Supplementary Material Figure S5b,c), although the absolute difference values of various GA components between two kinds of explants were not the same in all varieties.

As shown in Fig. 5, differences in the ABA and SA contents in the tips and upper leaf parts of variety T141 were highly significant. For ABA, tip explants produced the maximum value of $180.58 \mathrm{ng} / \mathrm{g}$ (Fig. 5a), while upper leaf part explants produced the lower ABA value of $123.89 \mathrm{ng} / \mathrm{g}$. In contrast, a greater SA level was observed in upper leaf part explants $(24.708 \mathrm{ng} / \mathrm{g})$, while a lower value $(11.40 \mathrm{ng} / \mathrm{g}$ ) was observed in tip explants (Fig. 5b).

Among the jasmonic hormones, JA, JA-ILE and H2JA showed significantly greater concentrations in the tip explants, at 531.05, 545.14 and $0.45 \mathrm{ng} / \mathrm{g}$, respectively (Fig. 6a-c) than those in upper leaf parts $(202.34,48.51$ and $0.17 \mathrm{ng} / \mathrm{g})$. However, the upper part of leaves was higher $(1.70 \mathrm{ng} / \mathrm{g})$ than tips $(0.60 \mathrm{ng} / \mathrm{g})$ in methyl jasmonate content (Fig. 6d). According to endogenous jasmonic results, the tips of varieties CK, T36 and T167 had the much higher values of JA and JA-ILE than those in the upper part of leaves (Supplementary Material Figure S6). 


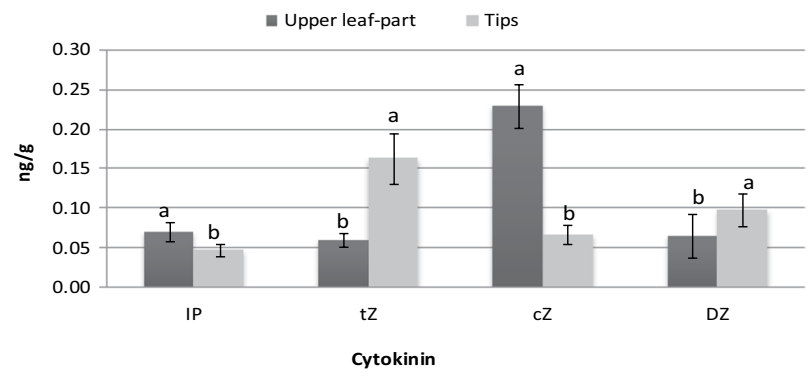

Figure 3. The contents of various endogenous cytokinins (IP, $t Z, c Z$ and DZ) in tips and upper leaf parts of variety T141. Data are presented as means \pm SDs $(n=3)$ and the different upper letters indicate significant differences at $P<0.05$ level according to LSD test.

a

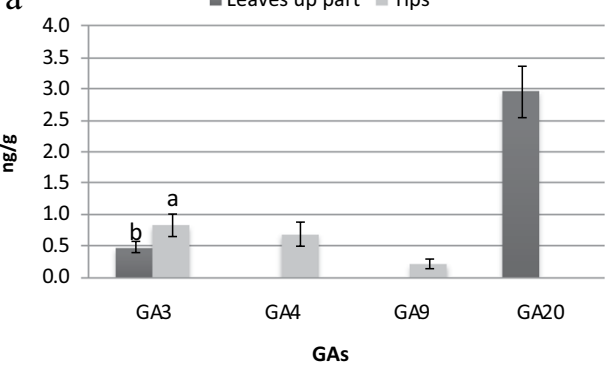

$\mathrm{b}$

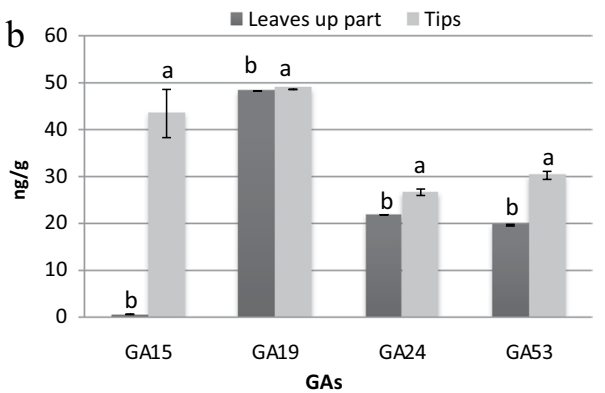

Figure 4. Gibberellin (GA) levels in different explants of variety T141: (a) GA3, 4, 9 and 20, (b) GA15, 19, 24 and 53. Data are presented as means \pm SDs $(n=3)$ and the different upper letters indicate significant differences at $P<0.05$ level according to LSD test.

a

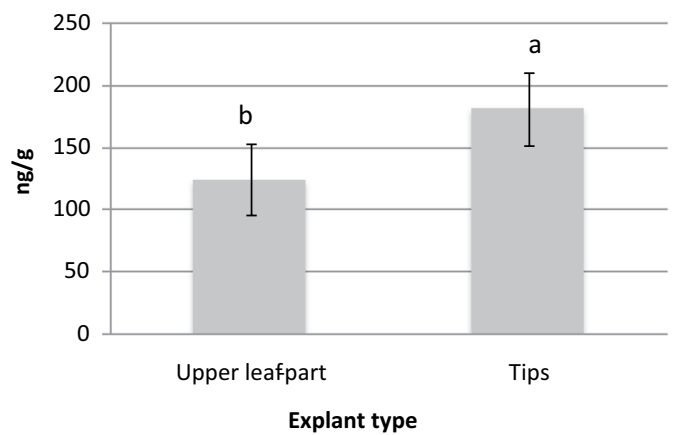

b

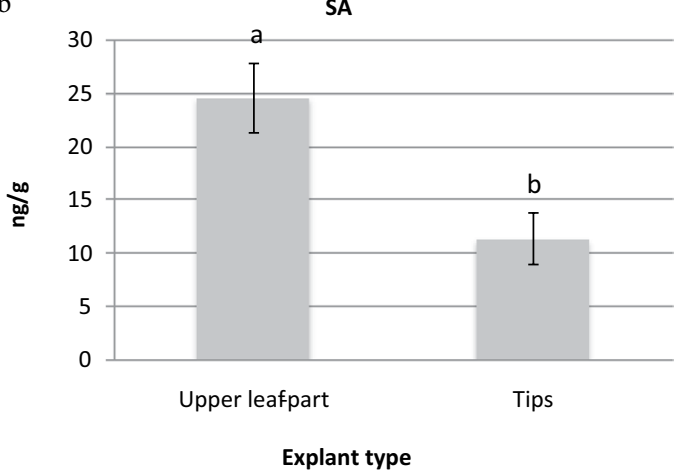

Figure 5. Means of (a) abscisic acid (ABA) and (b) salicylic acid (SA) concentrations in upper leaf part and tip explants of variety T141. Data are presented as means \pm SDs $(n=3)$ and the different upper letters indicate significant differences at $P<0.05$ level according to LSD test.

\section{Discussion}

In tissue culturing, callus induction is an important step in which mature organs dedifferentiate and develop numerous reproducible new plantlets. It is very important for tissue/organ regeneration, massive multiplication and the genetic improvement of plants, especially in vegetative propagated plants.

Our results corroborated previous findings that genotype plays a very important role in callus establishment, growth and subsequent differentiation ${ }^{24,28-30}$. The variations in callus formation and growth among varieties might result from genetic differences. Additionally, Pérez-Jiménez et al. ${ }^{17}$ reported that genotypes forming heavier calli might result from the tissues having a greater sensitivity to plant growth regulators.

Furthermore, explant selection is crucial in callus induction and the response of the explant is highly dependent on its genotype and physiological state. Therefore, different types of explants for any given species do not respond equally, resulting in different induction levels of embryogenic calli ${ }^{31,32}$. Here, tip explants produced the most calli during both primary culture and subculture, indicating that they are the best source for rapidly and economically massive producing garlic calli. Our results demonstrated previous reports on Chinese jiaotou ${ }^{2}$. Khar 
a

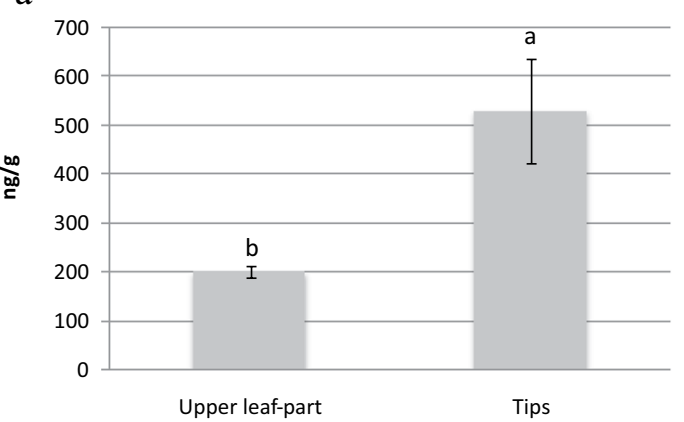

Explant type

$\mathrm{c}$

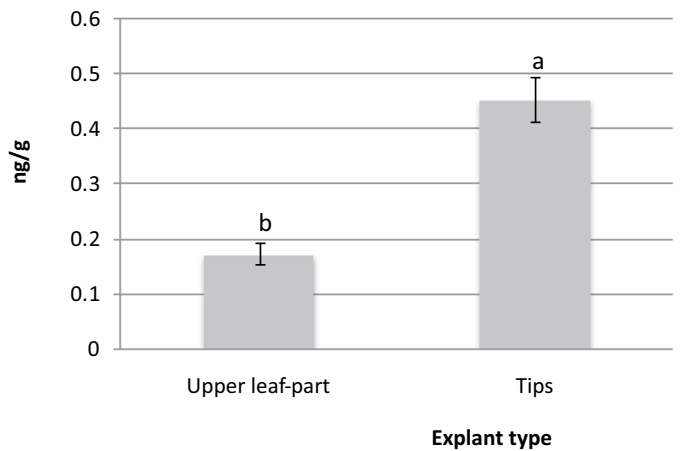

b

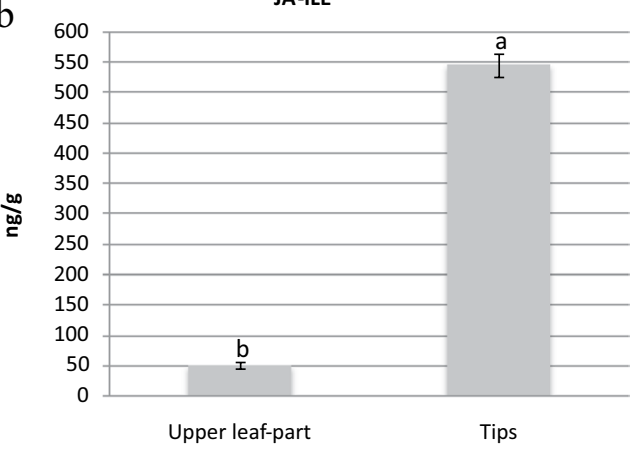

Explant type

d

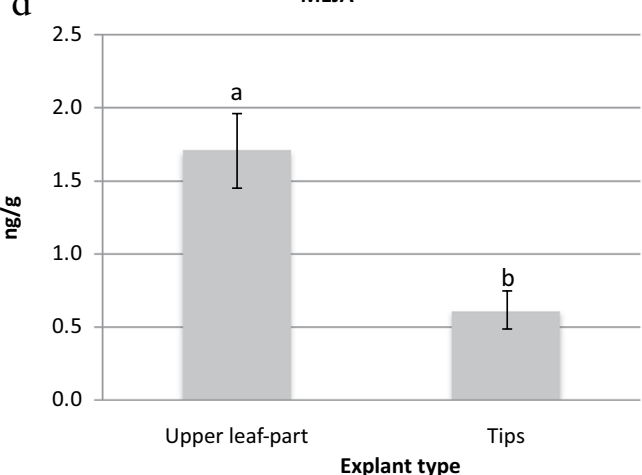

Figure 6. The contents of (a) Jasmonic acid (JA), (b) jasmonoyl-L-isoleucine (JA-ILE), (c) dihydrojasmonic acid (H2JA) and (d) methyl jasmonate (MEJA) in upper leaf parts and tips of variety T141. Data are presented as means $\pm \mathrm{SDs}(\mathrm{n}=3)$ and the different upper letters indicate significant differences at $P<0.05$ level according to LSD test.

et al. ${ }^{28}$ also reported that onion shoot-tip explants are the best source for callus formation. However, Luciani et al. ${ }^{9}$ found that basal plates were the best explants for callus differentiation in garlic, but this depends on whether there are shoot-tips remaining on basal plates. Differences in various parameters, such as the numbers of meristematic and parenchymal cells, could be related to the induction of cell division among different explant types, at least when regarding callus growth ${ }^{33}$.

The interaction effects between genotype and explant on callus induction were significant in our experiments. Thus, successful tissue culture and plant regeneration protocols are dependent on plant genotype, explant source and explant developmental stage $\mathrm{e}^{34,35}$. The tissues' physiological and metabolic states may be the most important factors for callus production.

Phytohormones are divided into various groups, such as auxins, gibberellins, cytokinins, gaseous compounds (i.e., ethylene), those associated predominantly with growth development and senescence (i.e., ABA), and recently found JA, brassinosteroids and $\mathrm{SA}^{33}$. Common exogenous applications of auxins and cytokinins can induce callus formation in various plant species. Also, in some plant species, brassinosteroids and ABA also play important roles in callus induction ${ }^{36,37}$. Although many studies have focused on the reactions of cell and tissue cultures to the supplementation of media with nutrients and phytohormones, investigations into the effects of the endogenous hormonal systems of cultured explants are rather limited ${ }^{33}$. Little experimental evidence is available even though it has been suggested that the endogenous hormone content in the initial explant can affect its capacity to form calli $^{25,38}$. In our study, the endogenous hormone levels of two explant types, tips and upper leaf parts of variety T141, were determined, and the contents of auxins (IAA and ME-IAA), most gibberellins (GA $3,4,9,15,24$ and 53 ), cytokinins (tZ), ABA and jasmonic group members JA, JA-ILF etc. were significantly greater in tip explants than those in upper leaf parts. The change trend for most hormones above was similar for other genotypes although the changes and the absolute difference values of some hormones between two kinds of explants were not the same in different genotypes. Growth regulator levels within explants, as endogenous factors, together with the interactions between endogenous and exogenous hormones, may also influence embryogenic responses ${ }^{30,39}$. The level of the endogenous auxin IAA was more than 10 times greater in tip explants than in upper leaf part explants. IAA level is correlated with callus propagation and maintenance ${ }^{40}$. In addition, the results are in accordance with those of Liu et al. ${ }^{41}$, in which the promotion of the callus growth in Murashige and Skooge medium supplemented with NAA and kinetin may be the result of the high levels of endogenous IAA and exogenous NAA accumulated in cultured soybean hypocotyl explants. Sasaki et al. ${ }^{42}$ and Jiménez and Bangerth ${ }^{26}$, showed that the IAA contents were greater in embryogenic cells than non-embryogenic cells in carrot. In contrast, Michalczuk et al. ${ }^{43}$ 
reported that embryogenic and non-embryogenic callus cells of carrot propagated on 2,4-D-containing medium had similar IAA levels. Additionally, Igielski and Kepczynska ${ }^{27}$ reported that in the Medicago truncatula M9-10a line, the amounts of endogenous GAs were probably sufficient for somatic embryogenesis and suggested that the endogenous GA levels may, in some cases, be sufficient for the proliferation of embryogenic calli and embryo development. Likewise, Jiménez and Bangerth ${ }^{24}$ found a significantly greater endogenous GA content in maize embryogenic calli compared with non-embryogenic cells. Our ABA level results supported those of Kiyosue et al. ${ }^{44}$, who reported that the endogenous ABA level in embryogenic carrot cells was 67.2 times greater than that in non-embryogenic cells per unit of fresh weight, and Jiménez and Bangerth ${ }^{26}$ found that the ABA level was 10 times greater. In addition, Kiyosue et al. ${ }^{44}$ suggested that a high endogenous ABA content might be essential to induce or maintain embryogenic competence in carrot culture systems. The findings of Charrière and Hahne ${ }^{45}$ and Pérez-Jiménez et al. ${ }^{17}$ suggested that there is a correlation between morphogenic capacity and endogenous ABA content. Moreover, here, the SA level was lower in the garlic tips than upper leaf parts. This is supported by the results of Quiroz-Figueroa et al. ${ }^{46}$, who suggested that a low SA concentration can induce the reprogramming of somatic cells, forcing them into the embryogenic stage, while at a high concentration this reprogramming may be inhibited. This confirmed the correlation between a lower endogenous SA concentration and improved callus induction ${ }^{47}$. Although most previous studies only focused on the hormone levels in the calli produced by tissue culturing, it is evident that greater levels of endogenous JA, IAA and GA hormones in explants are important for garlic callus formation and proliferation. The levels of these endogenous hormones could be used as indicators for the selection of suitable explants for callus production.

The physiological status of the tissues and endogenous hormone levels are of primary importance for tissue dedifferentiation and callus formation. According to Ikeuchi et al. ${ }^{37}$, plant meristem is the source of all tissues, and these generative activities are supported by a pool of stem cells residing within the meristem. Thus, the strong stimulation of these meristematic activities leads to ectopic callus induction. Therefore, tender tissues with high endogenous hormone (i.e., JA, IAA and $\mathrm{tZ}$ ) levels are more suitable for callus induction.

\section{Conclusion}

The effects of genotypes and explant types, as well as their interactions, on garlic callus formation were extremely significant. Stem tip explants were the most suitable, followed by interior leaves, for callus induction. The increase in callus growth rate decreased gradually as the subculture time was extended. Our investigation first demonstrated that greater levels of endogenous auxins (IAA and ME-IAA), gibberellins $\left(\mathrm{GA}_{3,4,9,15,24 \text { and } 53}\right)$ and jasmonic group members (JA, JA-ILF and H2JA) in stem tip explants might play important roles in promoting callus formation and multiplication. These results will help establish a feasible and effective protocol for garlic callus production.

\section{Materials and Methods}

Plant materials. The plant materials used in the current study between 2016 and 2017 consisted of four garlic varieties from China, Da Xing (CK), T36, T141 and T167, which were provided by the Department of Vegetables Germplasm Resource, Institute of Vegetables and Flowers, Chinese Academy of Agricultural Sciences, Beijing, China.

Experimental design and basic tissue culture procedure. Different explants of garlic cloves (interior leaves, exterior leaves, lower leaf part, upper leaf part and tips) from the four varieties were used for callus induction (Supplementary Material Figure S7). The experiments were set up in spilt-plot designs, with three replicates per treatment, 10 culture flasks per replication and 10 explants per flask. The main plot was assigned to garlic variety and the sub-plots were assigned to explants.

Healthy cloves were washed with running tap water for $30 \mathrm{~min}$ and sterilized by soaking in $75 \%$ ethanol for $30 \mathrm{~s}$. This was followed by surface sterilization with $2 \%$ sodium hypochlorite solution for 8 to $10 \mathrm{~min}$. After washing three times with sterile distilled water, the explants were detached from the surface-sterilized cloves, cut into 3-4-mm segments and then, cultured on callus induction medium for $45 \mathrm{~d}$.

Medium and culture condition. The basal medium, containing Murashige and Skooge ${ }^{48}$ nutrients supplemented with $0.5 \mathrm{mg} / \mathrm{l}$ naphthalene acetic acid (NAA), $3 \mathrm{mg} / \mathrm{l}$ 2,4-dichlorophenoxyactic acid (2,4-D), $0.2 \mathrm{mg} / \mathrm{l}$ 6-benzyl amino-adenine, $30 \mathrm{~g} / \mathrm{l}$ sucrose and solidified with $6 \mathrm{~g} / \mathrm{l}$ agar, was used as the callus initiation medium. For the weekly callus growth rate (GR) and weekly callus cumulative production, $\mathrm{B} 5^{49}$ medium (callus propagation medium) supplemented with $1 \mathrm{mg} / \mathrm{l} 2,4-\mathrm{D}, 0.1 \mathrm{mg} / \mathrm{l}$ 6-benzyl amino-adenine, $30 \mathrm{~g} / \mathrm{l}$ sucrose and $6 \mathrm{~g} / \mathrm{l}$ agar was used. The $\mathrm{pH}$ of the medium was adjusted to 5.8 before autoclaving. Calli were incubated at $23 \pm 2{ }^{\circ} \mathrm{C}$ with a 12/12 h (day/night photoperiod) using cool white fluorescent lamps.

Data collection for callus induction. The percentage of explants forming calli for the first time was determined once calli emerged from explants cultured in callus induction medium. However, the percentage of total explants producing callus, and the callus weight per flask (g) in primary cultures were measured after $45 \mathrm{~d}$ of culturing. Moreover, after $45 \mathrm{~d}$, calli were transferred to a new flask containing $25 \mathrm{ml}$ of callus propagation medium for subculturing, and then, the callus weights were recorded. Over four weeks, the callus cumulative production (g/flask) and callus growth rate (GR) were computed as follows:

$$
\mathrm{GR} 1=\frac{W 1-W 45 d}{W 45 d} \times 100,
$$




$$
\begin{aligned}
& \mathrm{GR} 2=\frac{W 2-W 1}{W 1} \times 100, \\
& \mathrm{GR} 3=\frac{W 3-W 2}{W 2} \times 100,
\end{aligned}
$$

and

$$
\mathrm{GR} 4=\frac{W 4-W 3}{W 3} \times 100,
$$

where W45d represents the callus weight after $45 \mathrm{~d}$ of primary culturing, and W1, W2, W3 and W4 represent the callus weights after the first, second, third and fourth weeks of subculturing, respectively.

Chemicals and regents. HPLC-grade acetonitrile (ACN) and methanol were purchased from Merck (Darmstadt, Germany). MilliQ water (Millipore, Bradford, MA, USA) was used in all experiments. All of the standards were purchased from Olchemim Ltd. (Olomouc, Czech Republic) and Sigma (St. Louis, MO, USA). Acetic acid was purchased from Sinopharm Chemical Reagent (Shanghai, China). The standards' stock solutions were prepared at $10 \mathrm{mg} / \mathrm{ml}$ concentrations in ACN. All stock solutions were stored at $-20^{\circ} \mathrm{C}$ until used. The stock solutions were diluted with ACN to working solutions before analysis.

Sample preparation, extraction and analysis. Fresh plant samples were prepared, immediately frozen in liquid nitrogen, and stored at $-80^{\circ} \mathrm{C}$ until further analyzed. The frozen samples (approximately $120 \mathrm{mg}$ fresh weight) were ground in liquid nitrogen to fine powders by grinding machine (MM 400, Retsch) at $30 \mathrm{~Hz}$ for $1 \mathrm{~min}$, homogenized, extracted with $1.2 \mathrm{ml}$ methanol/water $(8 / 2, \mathrm{v} / \mathrm{v})$ and stayed overnight at $4{ }^{\circ} \mathrm{C}$. The extracts were centrifuged at $12,000 \mathrm{~g}$ and $4^{\circ} \mathrm{C}$ for $15 \mathrm{~min}$. The supernatants were collected, evaporated to dryness under a nitrogen gas stream and reconstituted in methanol/water $(3 / 7, \mathrm{v} / \mathrm{v})$. The solutions were centrifuged, and the supernatants were collected for LC-MS analysis. The hormone measurements were carried out with nine replicates per explant.

The determinations of the contents of auxins (IAA, ME-IAA, indole-3-carboxaldehyde (ICA) and 3-indolebutyric acid); cytokinins (IP, cZ, tZ and DZ); gibberellins (GAs) $1,3,4,7,9,15,19,20,24$ and 53, ABA, salicylic acid (SA), methylsalicylate and the jasmonic group (JA, dihydrojasmonic acid $\left(\mathrm{H}_{2} \mathrm{JA}\right)$, methyl jasmonate and jasmonoyl-L-isoleucine), were performed using an LC-ESI-MS/MS system, includes Ultra Performance Liquid Chromatography, UPLC (Shim-pack UFLC SHIMADZU CBM30A, http://www.shimadzu.com.cn/) and Tandem mass spectrometry, MS/MS (Applied Biosystems 6500 Quadrupole Trap, http://www.appliedbiosystems.com.cn/) by Wuhan Metware Biotechnology Co., Ltd., Wuhan, China ${ }^{50-52}$.

HPLC conditions. The HPLC analytical conditions were as follows: HPLC column, Waters ACQUITY UPLC HSS T3 C18 $(1.8 \mu \mathrm{m}, 2.1 \mathrm{~mm} \times 100 \mathrm{~mm})$; solvent system, water $(0.04 \%$ acetic acid): acetonitrile $(0.04 \%$ acetic acid); gradient program, $95: 5 \mathrm{~V} / \mathrm{V}$ at $0 \mathrm{~min}, 5: 95 \mathrm{~V} / \mathrm{V}$ at $11.0 \mathrm{~min}, 5: 95 \mathrm{~V} / \mathrm{V}$ at $12.0 \mathrm{~min}, 95: 5 \mathrm{~V} / \mathrm{V}$ at $12.1 \mathrm{~min}$ and 95:5 V/V at $15.0 \mathrm{~min}$; flow rate, $0.35 \mathrm{ml} / \mathrm{min}$; temperature, $40^{\circ} \mathrm{C}$; and injection volume: $5 \mu$. The effluent was connected to an ESI-triple quadrupole-linear ion trap (Q TRAP)-MS.

ESI-Q TRAP-MS/MS. An API 6500 Q TRAP LC/MS/MS System, equipped with an ESI Turbo Ion-Spray interface, operating in a positive ion mode and controlled by Analyst 1.6 software (AB Sciex), was used. The ESI source operation parameters were as follows: ion source, turbo spray; source temperature, $500^{\circ} \mathrm{C}$; ion spray voltage, 5,500 V; curtain gas set at $35.0 \mathrm{psi}$; and the collision gas was medium. DP and CE values for individual MRM transitions were established by further optimization. A specific set of MRM transitions were monitored for each period based on the plant hormones eluted within the period.

Hormone qualitative and quantitative analysis. MWDB (metware database) plant hormone database was constructed based on plant hormone standard products, and then the data of mass spectrometry were analyzed qualitatively to characterize a substance according to its ion pair information (Q1, Q3, RT, DP and CE) (Supplementary Material Table S2). Hormone quantification was analyzed using multiple reaction monitoring (MRM) of triple quadrupole mass spectrometry system. The software Analyst 1.6.1 was used to process the mass spectrum data. Total ions current (TIC) and count per second (cps) were obtained (Supplementary Material Figure S8). The repeatability of hormone extraction and detection can be judged by overlapping display analysis of the total ion flow diagrams (TIC diagrams) of different quality control samples. According to the information of hormone retention time and peak pattern, the mass spectrum peaks detected in different samples for each hormone were corrected to ensure the accuracy of qualitative and quantitative analysis. The peak area of each chromatographic peak represented the relative content of corresponding hormones, and the results of quantitative analysis of all samples of hormones were finally obtained based on the standard curve of external standard method.

Plant hormone standard solutions with different concentrations of $0.02 \mathrm{ng} / \mathrm{mL}, 0.05 \mathrm{ng} / \mathrm{mL}, 0.1 \mathrm{ng} / \mathrm{mL}, 0.2 \mathrm{ng} /$ $\mathrm{mL}, 0.5 \mathrm{ng} / \mathrm{mL}, 1 \mathrm{ng} / \mathrm{mL}, 2 \mathrm{ng} / \mathrm{mL}, 5 \mathrm{ng} / \mathrm{mL}, 10 \mathrm{ng} / \mathrm{mL}, 20 \mathrm{ng} / \mathrm{mL}, 30 \mathrm{ng} / \mathrm{mL}, 50 \mathrm{ng} / \mathrm{mL}, 100 \mathrm{ng} / \mathrm{mL}, 200 \mathrm{ng} / \mathrm{mL}$, $400 \mathrm{ng} / \mathrm{mL}, 1600 \mathrm{ng} / \mathrm{mL}$ and $2000 \mathrm{ng} / \mathrm{mL}$ were prepared. Obtain the peak intensity data of mass spectrum corresponding to the quantitative signal of each standard concentration; Standard curves of different hormones were plotted (Supplementary Material Figures S9-13). 
The integral peak area of all detected hormones was substituted into the linear equations of the standard curves for calculation, and then the absolute content of hormones in the actual samples were obtained after further calculation as follows:

The content of hormone in the sample $(\mathrm{ng} / \mathrm{g})=\mathrm{B} * \mathrm{C} / 1000 / \mathrm{D} * \mathrm{E} / \mathrm{F} / \mathrm{g}$

Meaning of each letter in the formula:

B: concentration value $(\mathrm{ng} / \mathrm{mL})$ obtained by substituting the peak area of hormone integral in the sample into the standard curve;

C: volume of solution used in redissolution (100 mul);

D: volume of supernatant collected during sample extraction (1100 micron);

E: volume (mul) of extracted solution added during sample extraction;

F: standard recovery rate of hormone addition (\%);

G: weigh the sample mass (g).

Statistical analyses. An analysis of variance to determine the influences of different varieties, explants and their interactions was done using Statistix8.1 software ${ }^{53}$. A means separation was performed using the least significant difference test at $P=0.05$. Data are presented as the means \pm standard deviations.

Received: 20 February 2019; Accepted: 28 February 2020;

Published online: 17 March 2020

\section{References}

1. Nagakubo, T., Akitsu, N. \& Hideo, O. Micropropagation of garlic through in vitro bulblet formation. Plant Cell, Tissue and Organ Culture 32, 175-183 (1993).

2. Yan, M. M. et al. Effects of explant type, culture media and growth regulators on callus induction and plant regeneration of Chinese Jiaotou (Allium chinense). Scientia Horticulturae 123, 124-126 (2009).

3. Fereol, L. et al. Establishment of embryogenic cell suspension cultures of garlic (Allium sativum L.), plant regeneration and biochemical analyses. Plant Cell Rep. 24, 319-325 (2005).

4. Mukhopadhyay, M. J., Sengupta, P., Mukhopadhyay, S. \& Sen, S. In vitro stable regeneration of onion and garlic from suspension culture and chromosomal in stability in solid callus culture. Sci. Hortic. 104, 1-9 (2005).

5. Zheng, S. J. et al. Two different Bacillus thuringiensis toxin genes confer resistance to beet armyworm (SpodopteraexiguaHubner) in transgenic Bt-shallots (Allium cepa L.). Transgenic Res. 14, 261-272 (2005).

6. Yamashita, K., Hisatsune, Y., Sakamoto, T., Ishizuka, K. \& Tashiro, Y. Chromosome and cytoplasm analyses of somatic hybrids between onion (Allium cepa L.) and garlic (A. sativumL.). Euphytica 125, 163-167 (2002).

7. Liu, J., Xu, X. \& Deng, X. Intergeneric somatic hybridization and its application to crop genetic improvement. Plant Cell Tissue Organ Cult. 82, 19-44 (2005).

8. Zheng, S. J. et al. Factors influencing induction, propagation and regeneration of mature zygotic embryo-derived callus from Allium cepa. Plant Cell Tissue Organ Cult. 53, 99-105 (1998).

9. Luciani, G. F., Mary, A. K., Pellegrini, C. \& Curveto, N. R. Effects of explants and growth regulators in garlic callus formation and plant regeneration. Plant Cell Tiss Organ Cult. 87, 139-143 (2006).

10. Farhadi, N., Jaber, P., Alireza, M. A. \& Saeideh, A. S. Effect of explants type, growth regulators and light intensity on callus and plant regeneration in four ecotypes of Persian shallot (Allium hirtifolium). Scientia Horticulturae 218, 80-86 (2017).

11. Shuto, H., Abe, T. \& Sasahara, T. In vitro propagation of plants from root apex-derived calli in chinese chive (Allium tuberosum ROTTLER) and garlic (Allium sativum L.). Japan J. Breed. 43, 349-354 (1993).

12. Barandiaran, X., Martín, N., Rodríguez-Conde, M. F., Di-Pietro, A. \& Martín, J. Genetic variability in callus formation and regeneration of garlic (Allium sativum L.). Plant Cell Reports 18, 434-437 (1999).

13. Badria, F. A. \& Ali, A. A. Chemical and genetic evaluation of somaclonal variants of Egyptian garlic (Allium sativum L.). Journal of Medicinal Food 2(2), 39-43 (1999).

14. Salam, M. A. et al. Callus Induction and Regeneration of Indigenous Garlic (Allium sativum L.). American Journal of Plant Physiology 3, 33-39 (2008)

15. Janowicz, J., Niemann, J. \& Wojciechowski, A. The effect of growth regulators on there generation ability of flax (Linumusitatissimum L.) hypocotyl explants in in-vitro culture. Journal of Biotechnology, Computational Biology and Bionano technology 93(2), 135-138 (2012).

16. Aremu, A. O. et al. Endogenous cytokinin profiles of tissue-cultured and acclimatized 'Williams' bananas subjected to different aromatic cytokinin treatments. Plant Sci. 214, 88-98 (2014).

17. Pérez-Jiménez, M. et al. Relationship between endogenous hormonal content and somatic organogenesis in callus of peach (Prunus persica L. Batsch) cultivars and Prunus persica $\times$ Prunusdulcis rootstocks. Journal of Plant Physiology 171(8), 619-624, https://doi. org/10.1016/j.jplph.2014.01.006 (2014).

18. George, E. F. Plant Propagation by Tissue Culture. Part 1: The Technology, Exegetics Ltd, London, UK (1993).

19. Montalbán, I. A., Novák, O., Rolčik, J., Strnad, M. \& Moncaleán, P. Endogenous cytokinin and auxin profiles during in vitro organogenesis from vegetative buds of Pinus radiata adult trees. Physiol. Plant 148, 214-231 (2013).

20. Valdés, A. E., Ordás, R. J., Fernández, B. \& Centeno, M. L. Relationship between hormonal contents and the organogenic response in Pinus pinea cotyledons. Plant Physiol. Biochem. 39, 377-84 (2001).

21. Charrière, F., Sotta, B., Miginiac, E. \& Hahne, G. Induction of adventitious shoots or somatic embryos on in vitro cultured zygotic embryos of Helianthus annuus: variation of endogenous hormone levels. Plant Physiol.Biochem. 37, 751-7 (1999).

22. Haider, S. A. et al. In vitro plantlet regeneration of four local garlic (Allium sativum L.) accessions of Bangladesh. British Biotechnology Journal 8(3), 1-12 (2015).

23. Carnes, M. G. \& Wright, M. S. Endogenous hormone levels of immature corn kernels of A188, Missouri-17, and Dekalb XL-12. Plant Sci. 57, 195-203 (1988).

24. Jiménez, V. M. \& Bangerth, F. Hormonal status of maize initial explants and of the embryogenic and non-embryogenic callus cultures derived from them as related to morphogenesis in vitro. Plant science 160, 247-257 (2001c).

25. Jiménez, V. M. \& Bangerth, F. Endogenous hormone concentrations and embryogenic callus development in wheat. Plant Cell, Tissue and Organ Culture 67, 37-46 (2001a).

26. Jiménez, V. M. \& Bangerth, F. Endogenous hormone levels in explants and in embryogenic and non-embryogenic cultures of carrot. Physiologia Plantarum 111, 389-395 (2001b). 
27. Igielski, R. \& Kępczyńska, E. Gene expression and metabolite profiling of gibberellin biosynthesis during induction of somatic embryogenesis in Medicago truncatula Gaertn. PLoS One 12(7), e0182055, https://doi.org/10.1371/journal.pone.0182055 (2017).

28. Khar, A., Bhutani, R. D., Yavav, N. \& Chowdhury, V. K. Effect of explant and genotype on callus culture and regeneration in onion (Allium cepaL.). Akdeniz Üniversitesi Ziraat Fakultesi Dergisi 18(3), 397-404 (2005).

29. Bendif, H., Adouni, K. \& Boudjeniba, M. The effect of growth regulators and explants on callus induction in four cultivars of potato (Solanum tuberosum L.). Journal of Bioressources Valorization 2(1), 34-41 (2017).

30. Triqui, Z. E. et al. Effect of genotype, gelling agent, and auxin on the induction of somatic embryogenesis in sweet potato (Ipomoea batatas Lam.). C. R. Biologies 331, 198-205 (2008).

31. Trigiano, R. N. \& Gray, D. J. Plant development and biotechnology. CRC Press LLC, New York, ISBN: 0-8493-1614-6, pp: 358 (2005).

32. Dhiya-Dalila, Z., Jaafar, H. \& Abdul-Manaf, A. Effects of 2,4-D and kinetin on callus induction of Barringtoniaracemosa leaf and endosperm explants in different types of basal media. Asian Journal of Plant Sciences 12(1), 21-27 (2013).

33. Neumann, K. H., Kumar, A. \& Imani, J. Plant cell and tissue culture - A tool in biotechnology: Principles and practice, SpringerVerlag Berlin Heidelberg (2009).

34. Jain, R. K. Effect of some factors on plant regeneration from Indica rice cells and protoplasts - a review. Ind. J. Exp. Biol. 35, 323-331 (1997).

35. Hoque, M. E. \& Mansfield, J. W. Effect of genotype and explant age on callus induction and subsequent plant regeneration from root-derived callus of Indica rice genotype. Plant Cell, Tissue and Organ Culture 78, 217-223 (2004).

36. Navarro, C., Rosa, M. E. \& May, A. In vitro plant regeneration from embryogenic cultures of a diploid and triploid Cavendish banana. Plant Cell Tissue Org Cult. 51, 17-25 (1997).

37. Ikeuchi, M., Keiko, S. \& Akira, I. Plant Callus: Mechanisms of Induction and Repression. The Plant Cell Sep 25(9), 3159-3173, https://doi.org/10.1105/tpc.113.116053 (2013).

38. Kopertekh, L. G. \& Butenko, R. G. Naturally occurring phytohormones in wheat explants as related to wheat morphogenesis in vitro. Rus. J. Plant Physiol. 42, 488-491 (1995).

39. Jiménez, V. M. Involvement of plant hormones and plant growth regulators on in vitro somatic embryogenesis. Plant Growth Regul. 47, 91-110 (2005).

40. Centeno, M. L., Rodríguez, A., Feito, I. \& Fernández, B. Relationship between endogenous auxin and cytokinins levels and morphogenic responses in Actinidadelicios a tissue cultures. Plant Cell Rep. 16, 58-62 (1996).

41. Liu, Z. H., Wang, W. C. \& Yan, S. Y. Effect of hormone treatment on callus formation and endogenous indole-acetic acid and polyamine contents of soybean hypocotyls cultivated in vitro. Botanical Bulletin of Academia Sinica 38, 171-176 (1997).

42. Sasaki, K., Shimomura, K., Kamada, H. \& Harada, H. IAA metabolism in embryogenic and non-embryogenic carrot cells. Plant Cell Physiol. 35, 1159-1164 (1994).

43. Michalczuk, L., Ribnicky, D. M., Cooke, T. J. \& Cohen, J. D. Auxin levels at different stages of carrot embryogenesis. Phytochemistry 31, 1097-1103 (1992)

44. Kiyosue, T. et al. Endogenous levels of abscisic acid in embryogenic cells, non-embryogenic cells and somatic embryos of carrot (Daucus carota L.). Biochem. Physiol. Pflanz 188, 343-347, https://doi.org/10.1016/S0015-3796(11)80129-0 (1992).

45. Charrière, F. \& Hahne, G. Induction of embryogenesis versus caulogenesis on in vitro cultured sunflower (Helianthus annus L.) immature zygotic embryos: role of plant growth regulators. Plant Sci. 137, 63-71 (1998).

46. Quiroz-Figueroa, F. R., Rojas-Herrera, R., Galaz-Avalos, R. M. \& Loyola-Vargas, V. M. Embryo production through somatic embryogenesis can be used to study cell differentiation in plants. Plant Cell. Tissue Organ Cult. 86, 285-301, https://doi.org/10.1007/ s11240-006-9139-6 (2006).

47. Fraga, H. P. F. et al. Glutathione and abscisic acid supplementation influences somatic embryo maturation and hormone endogenous levels during somatic embryogenesis in PodocarpuslambertiiKlotzsch ex Endl. Plant Science 253, 98-106, https://doi.org/10.1016/j. plantsci.2016.09.012 (2016).

48. Murashige, T. \& Skooge, F. A revised medium for rapid growth and bioassays with tobacco tissue cultures. Physiol. Plant 15, 473-497 (1962).

49. Gamborg, O. L., Miller, R. A. \& Ojima, K. Nutrient requirements of suspension cultures of soybean root cells. Exp. Cell Res. 50, 151-158 (1968).

50. Ma, Z. et al. Simultaneous analysis of different classes of phytohormones in coconut (Cocos nucifera L.) water using highperformance liquid chromatography and liquid chromatography-tandem mass spectrometry after solid-phase extraction. Analytica Chimica Acta 610(2), 274-281, https://doi.org/10.1016/j.aca.2008.01.045 (2008).

51. Pan, X., Welti, R. \& Wang, X. Simultaneous quantification of major phytohormones and related compounds in crude plant extracts by liquid chromatography-electrospray tandem mass spectrometry [J]. Phytochemistry 69(8), 1773-1781 (2008).

52. Hao, Y. H. et al. Stable isotope labeling assisted liquid chromatography-electrospray tandem mass spectrometry for quantitative analysis of endogenous gibberellins. Talanta 144, 341-348, https://doi.org/10.1016/j.talanta.2015.06.056 (2015).

53. Analytical software. Statistix 8.1 for Windows analytical software. Tallahassee, Florida (2005).

\section{Acknowledgements}

This work was supported by grants from China Agriculture Research System (CARS-24-A-01), Talented Young Scientist Program for Asian and African countries from Ministry of Science and Technology of the People's Republic of China (2016-2017), the National Key Research and Development Plan of the Ministry of Science and Technology of the People's Republic of China (2016YFD0100204).

\section{Author contributions}

Li Xixiang and Hassan H.A. Mostafa conceived and designed the experiment. Hassan H.A. Mostafa did the experiment and analyzed the data. Wang Haiping and Song Jiangping helped sample preparation and data collection. Hassan H.A. Mostafa and Li Xixiang wrote the manuscript.

\section{Competing interests}

The authors declare no competing interests.

\section{Additional information}

Supplementary information is available for this paper at https://doi.org/10.1038/s41598-020-61564-4.

Correspondence and requests for materials should be addressed to X.L.

Reprints and permissions information is available at www.nature.com/reprints.

Publisher's note Springer Nature remains neutral with regard to jurisdictional claims in published maps and institutional affiliations. 
(c) (i) Open Access This article is licensed under a Creative Commons Attribution 4.0 International License, which permits use, sharing, adaptation, distribution and reproduction in any medium or format, as long as you give appropriate credit to the original author(s) and the source, provide a link to the Creative Commons license, and indicate if changes were made. The images or other third party material in this article are included in the article's Creative Commons license, unless indicated otherwise in a credit line to the material. If material is not included in the article's Creative Commons license and your intended use is not permitted by statutory regulation or exceeds the permitted use, you will need to obtain permission directly from the copyright holder. To view a copy of this license, visit http://creativecommons.org/licenses/by/4.0/.

(C) The Author(s) 2020 